\title{
Dynamic Linkages Among U.S. Real Estate Sectors Before and After the Housing Crisis
}

\author{
Nafeesa Yunus ${ }^{1}$
}

Published online: 21 November 2017

(C) Springer Science+Business Media, LLC 2017

\begin{abstract}
This study explores the dynamic nature of linkages among seven key real estate sectors which include residential, health, lodging-resort, storage, office, retail and industrial. Long-run results reveal evidence of increased integration and contagion across the real estate sectors in the wake of the housing crisis. Short-run analyses suggest bi-directional causality and indicate that shocks to one real estate sector have a much more severe and persistent impact on other real estate sectors during the post-crisis period in comparison to the pre-crisis period. Finally, ripple effects are observed across the real estate sectors with shocks emanating from the "dominant" residential sector and spilling over to other real estate sectors.
\end{abstract}

Keywords Real estate sectors $\cdot$ Housing crisis $\cdot$ Ripple effects $\cdot$ Contagion $\cdot$ Portfolio · Diversification

JEL Classification $\mathrm{C} 22 \cdot \mathrm{C} 58 \cdot \mathrm{G} 1 \cdot \mathrm{G} 11 \cdot \mathrm{F} 15$

\section{Introduction}

The 2007-2008 housing crisis, which was catalyzed by the meltdown of the U.S. housing market has renewed the interest of academics and practitioners to reexamine the issue of financial market contagion - a significant increase in the

Nafeesa Yunus

Nafeesa.yunus@gmail.com

1 Department of Finance and Economics, Merrick School of Business, The University of Baltimore, 1420 North Charles Street, Baltimore, MD 21201, USA 
degree of linkages among sectors and asset markets during periods marked by financial turmoil and economic chaos. ${ }^{1}$ Most recent literature have found that the housing crisis was instrumental in increasing the level of convergence among the stock, bond, and commodity sectors implying that the housing crisis/global financial crisis (GFC henceforth) minimized the scope of diversification across these financial asset sectors.

The focus of previous research however has been predominantly on the stock, bond, and commodity sectors. Surprisingly, even though real estate has been an integral component of institutional investors portfolio, no published study has analyzed how the real estate sectors were affected by the housing crisis. Thus, the primary objective of this study is to fill the gap in the existing literature and evaluate the extent of linkages among seven key of real estate sectors (residential, health, lodging-resort, storage, office, retail and industrial) prior to and after global financial crisis. The analysis covers a twenty one year period beginning January 1994 and ending December 2014 and addresses the following critical questions:

1. Can the real estate sectors be categorized as unit root or trend stationary processes and did they undergo a structural break during the period under investigation?

2. Are real estate sectors integrated over the long-run and is there evidence of contagion across these sectors in the wake of the housing crisis?

3. Are these sectors interrelated over the short-run and was the GFC instrumental in changing the short-term relationships?

4. What effect do the shocks from one real estate sector have on others, how long do these shocks persist and do they have a permanent or temporary effect on the remaining sectors?

5. And finally, do shocks originate from one particular sector and subsequently ripples across to all remaining sectors?

The study makes several critical contributions: First it examines the stochastic time series properties of a comprehensive list of individual real estate sectors. In addition, it utilizes structural break tests to evaluate whether evidence of statistically significant breaks can be found in the wake of the housing crisis.

Second, the study compares the extent of linkages among the real estate sectors over the entire period (1994-2014), the pre-crisis period (1994-2008), and the post-crisis (20082014) periods to understand the dynamic nature of linkages among the sectors over the long-run, and to evaluate if contagious behavior can be observed across the sectors. Third, the study scrutinizes short-run (lead-lag) relationships and ripple effects prior to and after the crisis to evaluate how shocks from one sector affects the other, whether these shocks have a permanent or transitory effect, and whether shocks originate from one or more sectors and eventually spills overs and gets transmitted to the other sectors.

To the author's knowledge this is the first study that utilizes a comprehensive set of modern day techniques to evaluate contagious behavior and ripple effects across a wide array of real estate sectors. Overall, these findings are of interest to institutional

\footnotetext{
${ }^{1}$ Hamao et al. (1990), King and Wadhwani (1990), Sheng and Tu (2000), Forbes and Rigobon (2002) Rezayat and Yavas (2006), Chiou (2009), Dooley and Hutchison (2009), Chan et al. (2011), Guo et al. (2011), and Khaled et al. (2011) among others.
} 
investors who regularly invest across real estate sectors and fund managers who create real estate funds and ETFs based on the long-run and short-run attributes of these sectors in making more informed decisions (Webb 1984; Louargand 1992; Wit 1996, and Lee and Stevenson 2005).

The remainder of the paper is organised as follows: Section "Commonalities Across U.S. Real Estate Property-Type" discusses the theoretical rationale as to why real estate property types should be trending together in the long-run and converging over time; Section "Literature Review" presents a relevant literature review; Section "Data" sets forth a brief description of the data; Section "Empirical Methodology" discusses the methodology; Section "Empirical Results" examines empirical results; and, finally, Section "Conclusion" contains concluding remarks.

\section{Commonalities Across U.S. Real Estate Property-Type}

An important issue that has not received much attention in the prevailing literature is the theoretical rationale as to why real estate property types should be trending together in the long-run and converging over time. Therefore, in this section, we review the pertinent research that examines the potential "drivers" of real estate sub-markets in order to address this critical issue. ${ }^{2}$

A number of studies have found the real estate sector (as a whole) to be influenced by the same key macroeconomic fundamentals that affect other kinds of financial asset classes. For instance, Darrat and Glascock (1993) show that real estate markets are affected by the term structure of interest rates, industrial production and money base. Similarly, Ling and Naranjo (1999) and Quan and Titman (1999) find that real estate markets are integrated with the stock market and attribute the relationship to the macroeconomic fundamentals, that affect both stock markets and real estate markets. Similar results are reported in Liow and Yang (2005), Yunus (2012) and Bates et al. (2015) who find that real estate markets are integrated with stock market and several macroeconomic factors including GDP, inflation, short term rates, money supply and conclude that conditions in the macro-economy are critical for the real estate economy.

A handful of studies have taken the analysis a step further and indicated that even at the more granular level, real estate property types are linked with key macroeconomic fundamentals. For instance, McCue and King (1994) show that prices, nominal interest rates, inflation, output and investment all directly influence real estate property types. Similarly, Ling and Naranjo (1996) show that the growth rate in real per capita consumption, real T-bill rate, the term structure of interest rates and unexpected inflation influence real estate property sectors. Case et al. (2000) illustrate that integration across real estate markets and sub-sectors are due in part to common exposure to fluctuations in GDP. Overall, the results of these studies indicate that there are indeed commonalities across real estate sectors by suggesting that key economic indicators are permanent drivers that systematically affect individual property types over time.

Since studies have indicated that linkages among real estate markets arise due to the transmission of common market wide (systematic) shocks, and due to the fact that key macroeconomic indicators have been known to converge over time (historically),

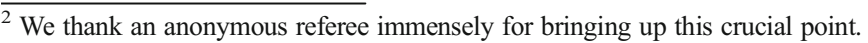


which has contributed to commonality across domestic business cycles, ${ }^{3}$ it is reasonable to expect real estate property types to be trending together over the long-run and converging over time. ${ }^{4}$

\section{Literature Review}

Numerous studies have evaluated asset asset market linkages during periods of economic crisis. With the onset of the 2007-2008 housing crisis, a growing strand of research has emerged that attempt to evaluate the effect of the housing crisis on stock, bond and commodity sectors. ${ }^{5}$ Most of these studies have concluded that the housing crisis was instrumental in increasing the level of convergence among these sectors thereby reducing their diversification potential. However, despite the increased recognition of real estate as a distinct asset class that deserves strategic allocation within portfolios, no study to date has examined the effect of the crisis on key real estate sectors.

The vast majority of studies concentrating on real estate sectors have focused primarily on its diversification potential and compared its diversification attributes to those attained by investing across real estate geographic regions. An early study evaluating the benefits of real estate sector versus regional diversification is conducted by Miles and McCue (1982). Focusing on the U.S. REIT market, these authors show that, in general, real estate improves the risk-adjusted performance of multi-asset class portfolios. Their findings also suggest that diversification by real estate sector showed better results than those achieved by means of geographic diversification. Extending their earlier work, Miles and McCue (1984) used data from a large commingled real estate fund of the U.S. and also found that diversification across real estate sector improved the risk return attributes of the portfolios more than diversification by regions.

Similar results are reported in Eichholtz et al. (1995) who perform a comparative analysis and evaluate whether sectoral diversification provided greater benefits than regional diversification in the U.K and the U.S. Their results suggest that for the U.S. diversification across real estate sector is more effective but for the U.K., diversification within both real estate sector and within regions is equally effective. Fisher and Liang (2000), find similar results for the U.S. and recommend real estate portfolio managers to pay more attention to the property sector allocation when making their real estate investment decisions.

Focusing on the Asia-Pacific region, Addae-Dapaah and Yong (2000) show that diversifying investments internationally by sector is a better strategy than other forms of strategies while Newell and Keng (2003) find that that both property sector and geographic diversification delivered significant diversification benefits for Australia. ${ }^{6}$

\footnotetext{
${ }^{3}$ See for instance Long and Plosser (1987), Durlauf (1989), Engle and Issler (1995), Case et al. (2000), Hamelink et al. (2000), MacGregor and Schwann (2003) and Francis and Ibbotson (2009) among others.

${ }^{4}$ The list of hypothesis tests appear after the methodology section.

${ }^{5}$ See for instance Dooley and Hutchison (2009), Chan et al. (2011), Guo et al. (2011), Kenourgios et al. (2011) and Khaled et al. (2011) among others.

${ }^{6}$ It is important to note that a handful of studies have also found that greater diversification benefits can be achieved across regions. See for instance Mueller and Ziering (1992) and Mueller (1993) among others.
} 
Glascock and Kelly (2007) examine and test the merits of diversifying portfolios of real estate securities internationally and across property types. They find that property type effects are smaller than country effects. They show that property type specialization explains only $6 \%$ of the variance of national real estate securities index returns and contend that country diversification is a more effective tool for achieving risk reduction than property type diversification. In addition, they also find that the relative importance of country effects is decreasing while that of industry effects is increasing.

In a related Wit (2010) disentangles the performance of international real estate into property type performance and regional selection. The author shows that the average variance of the regional effects is higher than the property type effects and conclude that the regional effects have a higher influence on the variation of the total portfolio. However, he finds that the regional effects are less stable through time, compared with the variance and correlation of the property type effects. Finally, the author find that property type effect be the more important factor for the return over time.

Finally, a recent study by Yunus (2013) evaluates the convergence patterns and diversification attributes of real estate sectors (retail, office, industrial and residential), of the U.S. and several developed countries. The results indicate that the real estate sectors for the UK, Netherlands, and Canada have fully converged over time, limiting their diversification potential. However the study also finds that for Finland, Sweden, Germany and France, the industrial sector provides the greatest diversification potential and thus deserve allocation within portfolios.

In summary, most of the above mentioned studies have shown that diversification across real estate sector is more advantageous and effective than regional diversification. Moreover, another strand of related research has also suggested that institutional investors and investment management firms actually prefer diversifying across key real estate categories rather than across property regions (Webb 1984, Louargand 1992, Wit 1996 and Lee and Stevenson 2005). In comparison to the above mentioned studies, the current study analyzes the dynamic interactions among seven key real estate sectors of the U.S. It contributes to the literature by (1) implementing a number of tests to determine the stochastic properties of each series and evaluating whether structural breaks exist within the sectors, (2) applying multivariate cointegration technique to appropriately model interactions among sectors in order to analyze whether contagious behavior can be observed across the sectors after the onset of the GFC, (3) evaluating causal linkages among the sectors to understand lead-lag relationships and (4) utilizing impulse response function analysis to examine short-run relationships and ripple effects prior to and after the most recent housing crisis.

\section{Data}

The dataset have been provided by the European Public Real Estate Association (EPRA) in connection with the National Association of Real Estate Investment Trusts (NAREIT) over a period beginning January 1994 and ending December 2014. The seven real estate sectors analyzed include residential, health, industrial, lodge-resort, 
office, retail, and storage. The purpose of these individual indexes is to provide investors with an overview of the risk-reward profiles of the different categories of real estate. The indexes also provide potential investors with a better understanding of the real estate investable universe which may enable them to make more optimal real estate investment decisions. ${ }^{7}$

The composition of the indexes is such that they consist of (REITs) or (LPTs) in which $75 \%$ or more of the gross invested book assets are invested in properties of that particular sector. For instance, the residential index consists of (REITs) or (LPTs) in which $75 \%$ or more of the gross invested book assets are invested in residential home properties; the self storage index consists of (REITs) or (LPTs) in which $75 \%$ or more of the gross invested book assets are invested in self storage properties and so on and so forth.

Table 1 summarizes the market value of each index for 2013, 2014 and 2015 respectively. It is apparent the market capitalizations have gone up considerably over the past three years with the retail sector dominating the others during each of the three year period.

Figure 1 shows the movement of the real estate sectors over time and as expected, the property sectors peaked somewhere around 2007 before eventually plummeting, rising in value only towards the end of 2008. Table 2 provides basic summary statistics of each index over the entire period (1994-2014) and shows that the storage sectors yielded the highest return while the lodge-resort sector fared the worst. On the risk side, however, the apartment/residential sector is found to be the least risky sector while the lodge-resort sector is found to be the riskiest. For ease of comparison, the risk-return relationships and attributes are repeated in a graphical format in Fig. 2.

The finding that for several of the sectors the "high-risk high return" relationship does not hold is surprising but it consistent with the recent stream of studies which indicate that lower risk securities tend to outperform high-risk securities after accounting for risk (Ang et al. 2006, 2009 and Blitz et al. 2013).

\section{Empirical Methodology}

Several econometric techniques are employed to understand the underlying nature of interlinkages among the real estate sectors and to evaluate the effects of the housing crisis on these sectors. The statistical tests and econometric procedures are summarized in the next few subsections.

\section{Unit root tests}

Before proceeding with subsequent analysis it is important to appropriately characterize the univariate properties of the indexes under consideration. A battery of tests is used to evaluate the stochastic time series properties of each series: They include the $\mathrm{Ng}$ and Perron (2001) test, the Zivot and Andrew's (1992) test, Perron's (1997) test, and the Lee and Stratizich's (2003) test.

First, the Ng and Perron (2001) test is used to examine whether unit roots exist within the data. The test uses the generalized least squares detrending procedure (developed by

\footnotetext{
${ }_{7}$ Detailed description is freely available in the "Ground Rules for Management of the FTSE EPRA/NAREIT Global Real Estate Index series" version November 2014, pages 38-39.
} 
Table 1 Market Capitalization (USD 000's)

\begin{tabular}{llll}
\hline Index & 2015 & 2014 & 2013 \\
\hline Retail Index & $\$ 186,804.18$ & $\$ 182,186.66$ & $\$ 129,899.77$ \\
Residential Index & $117,795.87$ & $110,047.38$ & $79,334.68$ \\
Healthcare Index & $94,206.95$ & $91,325.96$ & $64,746.70$ \\
Office Index & $89,782.75$ & $80,053.92$ & $59,484.15$ \\
Lodging/Resorts Index & $51,882.27$ & $54,150.10$ & $36,728.74$ \\
Self Storage Index & $42,358.92$ & $39,728.59$ & $30,644.11$ \\
Industrial Index & $31,945.49$ & $30,420.75$ & $25,237.04$ \\
Total & $683,347.48$ & $658,610.80$ & $487,615.74$ \\
\hline
\end{tabular}

Table 1 shows the market capitalization USD 000's for each sector over the last three years

Elliott et al. 1996) to create "efficient" versions of the Phillips and Perron (1988) tests. The following two tests, collectively known as the $\mathrm{Ng}$ and Perron (2001) $M$ tests are $M Z_{\alpha}$ and $M Z_{t}$ :

$$
\begin{gathered}
M Z_{\alpha}=\left(T^{-1} y_{t}^{2}-s_{A R}^{2}\right)\left(2 T^{-2} \sum_{t=1}^{T} y_{t-1}^{2}\right)^{-1} \\
M Z_{t}=M Z_{\alpha} \times M S B
\end{gathered}
$$

where $T$ is the total number of usable observations, $y_{t}=u_{t}+d_{t}, d_{t}=\varphi^{\prime} z_{t}, z_{t}$ is a set of deterministic components, $u_{t}=\alpha u_{t-1}+v_{t}, s_{A R}^{2}$ is an autoregressive estimate of the

\section{Time-series plot of seven property sectors}

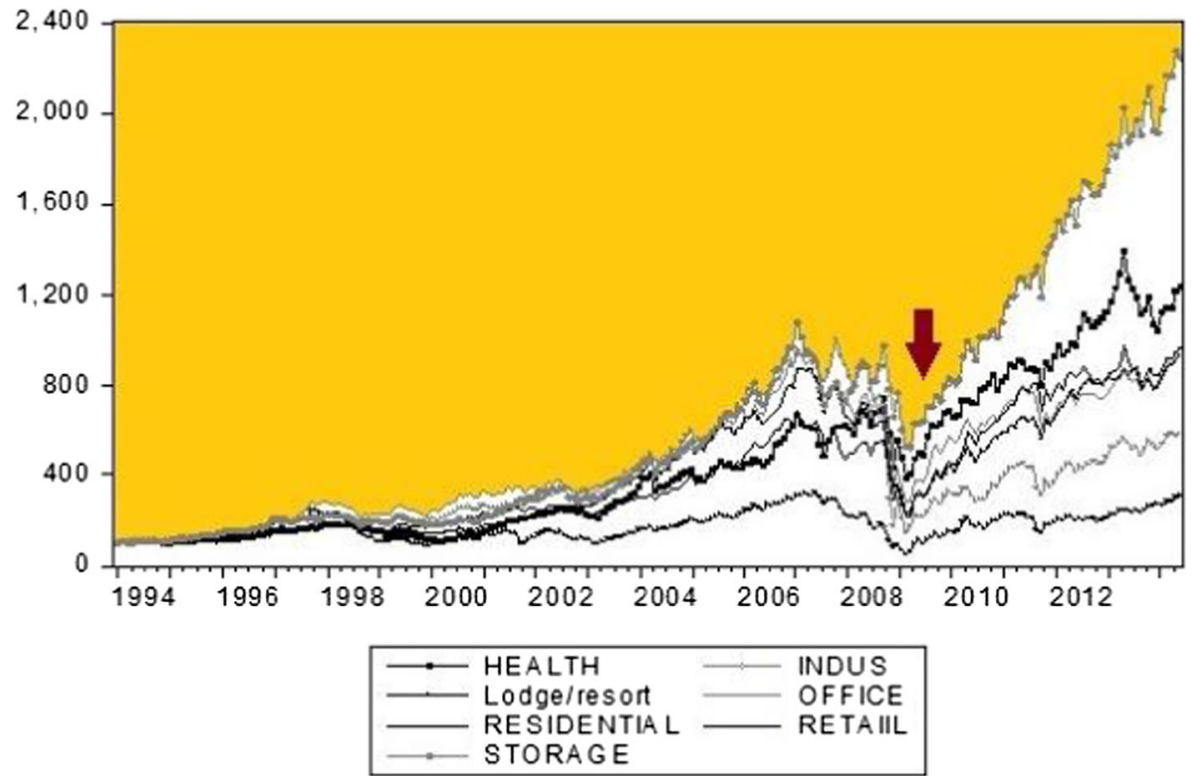

Fig. 1 Note: Fig. 1 depicts the movement of each seven property sector indexes from 1993 to 2014 
Table 2 Descriptive statistics

\begin{tabular}{llllll}
\hline Sector & Mean & Std Dev. & Skewness & Kurtosis & Jarque-Bera \\
\hline Residential & 1.09 & 5.68 & -0.79 & 7.10 & 197.48 \\
Health & 1.22 & 6.02 & -0.35 & 6.74 & 147.54 \\
Industrial & 1.16 & 9.02 & 0.27 & 25.69 & 5260.46 \\
Lodge-Resort & 0.86 & 9.06 & 0.95 & 16.03 & 1769.61 \\
Office & 1.13 & 6.30 & -0.50 & 9.17 & 398.26 \\
Retail & 1.15 & 6.56 & -0.35 & 15.80 & 1676.80 \\
Storage & 1.44 & 5.72 & -0.49 & 5.22 & 59.95 \\
\hline
\end{tabular}

The (J-B) Jarque-Bera statistic tests the null hypothesis of a normal distribution and is distributed as a $\chi^{2}$ with 2 degrees of freedom

spectral density of frequency zero of $v_{t}$ and $M S B=\left(T^{-2} \sum_{t=1}^{T} \frac{y_{t-1}^{2}}{s_{A R}^{2}}\right)^{1 / 2} \cdot \mathrm{Ng}$ and Perron (2001) demonstrate that these $M$ tests have similar power properties and superior size properties relative to the tests developed by Phillips and Perron (1988) when the lag length is chosen using the modified Akaike information criterion.

Next, the Zivot and Andrew's (1992) test, Perron's (1997) test, and the Lee and Stratizich's (2003) test analyze the existence of (or lack thereof) structural breaks endogenously within the data generating processes in addition to testing for the evidence of non-stationarity in the data. Zivot and Andrews (1992) and the Perron (1997) tests for structural breaks are merely extensions of the augmented Dickey and Fuller (1979, 1981) tests, ${ }^{8}$ but whereas Zivot and Andrews (1992) recommends determining the break point where the unit root $t$-test statistic is minimized within the ADF regressions, (Perron 1997) recommends selecting the break point by examining the significance of the dummy variables used in the regression equations. Finally, for robustness purposes, a recent test developed by Lee and Stratizich (2003) and further refined by Lee and Stratizich (2013), that yields good power and reliable size properties is also implemented to accurately determine the approximate break point in the DGPs.

\section{Long-Run Analysis: Cointegration Tests}

The maximum likelihood estimation technique introduced by Johansen (1988) and further refined by Johansen and Juselius (1990) is employed to estimate the number of long-run equilibrium relationships among the sectors and to examine whether the GFC increased the degree of linkages among these sectors. Johansen's (1988) and Johansen and Juselius's (1990) analysis starts by considering an $n$ variable first order vector auto regression (VAR) given by:

$$
x_{t}=\mu+A_{1} x_{t-1}+\cdots+A_{k} x_{t-k}+\varepsilon_{t}
$$

where $x_{t}$ is an $n$ dimensional vector comprised of all the real estate sectors, i.e., $x_{t}=$

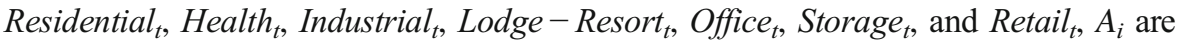

\footnotetext{
${ }_{8}^{8}$ Detailed explanations of the Dickey Fuller tests can be found in Dickey and Fuller $(1979,1981)$.
} 


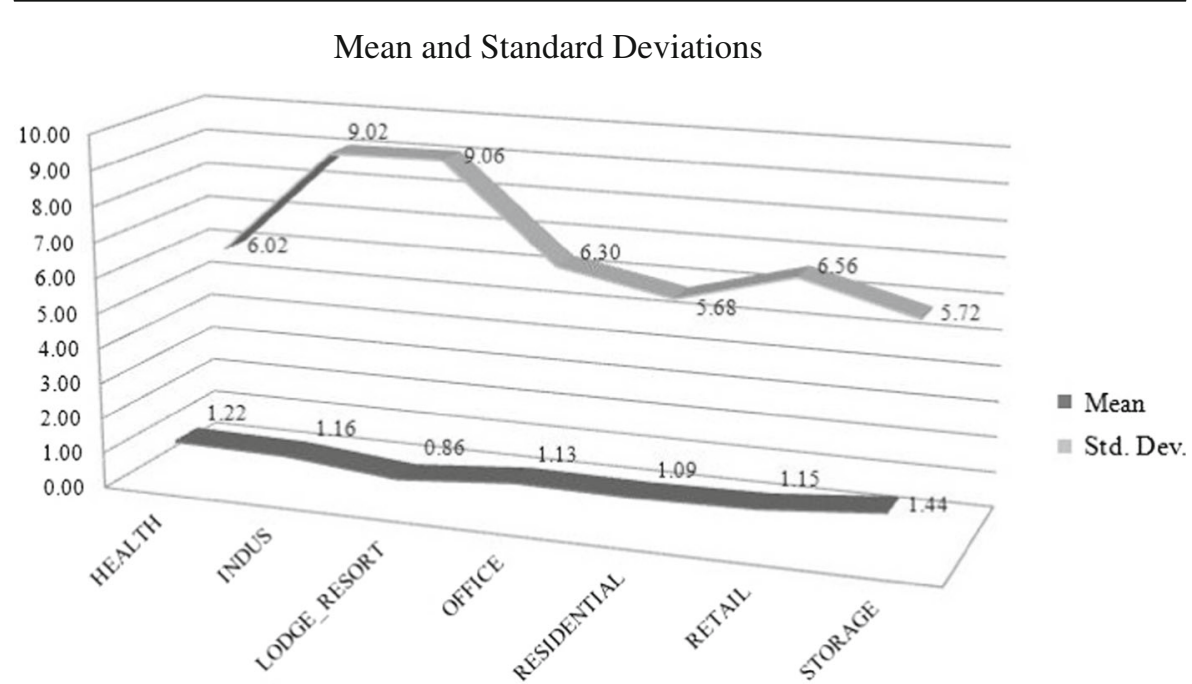

Fig. 2 Note: Fig. 2 shows the means and standard deviations of returns for each of the seven real estate sectors

$n \times n$ coefficient matrices, $\mu$ is the matrix composed of all the deterministic components, $\varepsilon_{t}$ are white noise error terms IN $\left[0, \sigma_{\varepsilon}^{2}\right]$, and finally $k$ is the lag length of the VAR system. After subtracting $x_{t-1}$ from both sides of Eq. 3, the VAR above can be transformed into an error correction model:

$$
\Delta x_{t}=\mu+\Gamma_{1} \Delta x_{t-1}+\ldots .+\Gamma_{k-1} \Delta x_{t-k+1}+\Pi x_{t-1}+\varepsilon_{t}
$$

where $\Delta$ is the difference operator, is $\Gamma_{i}$ is an $n \times n$ coefficient matrix equal to $-\left(I-A_{1}-\ldots\right.$ - $\left.A_{i}\right)$, for $(i=1, \ldots k-1)$, representing short-run dynamics, while $\Pi$ is an $n \times n$ matrix equal to $-\left(I-A_{1}-\ldots-A_{k}\right)$ whose rank determines the number of distinct cointegrating vectors that exist among the variables in $x_{t}$. Johansen suggests two test statistics to determine the rank of the $\Pi$ matrix, the $\lambda_{\text {Trace }}$ test and the $\lambda_{\text {Max }}$ test:

$$
\begin{gathered}
\lambda_{\text {Trace }}(r)=-T \times \sum_{i=r+1}^{n} \ln \left(1-\widehat{\lambda}_{i}\right) \\
\lambda_{\text {Max }}(r, r+1)=-T \times \ln \left(1-\widehat{\lambda}_{r+1}\right)
\end{gathered}
$$

In these equations, $T$ represents the number of usable observations, $\lambda_{i}$ represents the eigenvalues obtained from the $\Pi$ matrix and the significance of the $\lambda_{i}$ determines the appropriate rank of the matrix.

If the sectors are found to be cointegrated, exclusion tests are applied to analyze whether each of the sectors belong to the cointegrating relationships or if one or more can be excluded. In essence if there are $r$ cointegrating vectors, the $\Pi$ matrix in equation Eq. (4) can be decomposed into two $n \times r$ matrices such that $\Pi=\alpha \beta$ where $\beta$ is the matrix comprised of the cointegrating vectors and $\alpha$ is the matrix composed of the speed of adjustment parameters. The exclusion tests are conducted in the following manner: First, a design matrix $H$ is formulated such that $\beta=H^{*} \varphi$, where the dimension 
of the $H$ matrix will be $n \times(n-m)$ where $n=$ number of variables and $m=$ number of restrictions while $\varphi=(n-m) \times r$. The null hypothesis is $H_{0}: \beta_{i}=0$ while the alternative the $H_{a}: \beta_{i} \neq 0$. Depending on which variable is tested to examine for exclusion purposes, the corresponding row of the $\beta$ matrix is set to 0 .

As an example, in a simplified system, let us assume that there are only 3 variables $(X 1, X 2, X 3)$, they are bound together by 1 cointegrating relationship, and we would like to test the hypothesis that $\beta_{3}=0$ or that the variable $X 3$ is excludable. As illustrated in eq. (7), the dimension of the $H$ matrix would then be $3 \times 3$ while the dimension of the $\varphi$ matrix will be $2 \times 1$ and thus the dimension of the matrix $\beta=3 \times 1$. The test statistics are $\chi^{2}(r)$ distributed with $\chi^{2}(r) \times[n-(n-m)]$ degrees of freedom. The analysis can of course be extended to the real estate sectors that is analyzed in the current study.

$$
\left(\begin{array}{l}
\beta_{1} \\
\beta_{2} \\
\beta_{3}
\end{array}\right)=\left(\begin{array}{lll}
1 & 0 & 0 \\
0 & 1 & 0 \\
0 & 0 & 0
\end{array}\right) \times\left(\begin{array}{l}
\varphi_{11} \\
\varphi_{21}
\end{array}\right)
$$

\section{Spanning Tests}

After conducting cointegration tests, we evaluate whether and how the addition of the individual property types enhances portfolio diversification benefits by performing regression-based spanning tests. ${ }^{9}$ Huberman and Kandel (1987) are one of the first authors to develop mean variance spanning tests. The authors start out their analyses with a set of $K$ benchmark asset(s). They then evaluate whether the addition of a set of $N$ test asset(s) provide diversification benefits over and above the $K$ benchmark asset(s). Huberman and Kandel's regression based spanning tests are very simple to implement and involve the regression of the test asset(s) against a set of benchmark asset(s):

$$
\text { TestAsset }_{i}=\alpha_{\mathrm{i}}+\beta_{1}{ }^{*} \text { BenchamarkAsset }(s)+\varepsilon_{i}
$$

The null hypothesis is that of spanning which would imply that the meanvariance frontier of a set of $K$ assets and that of the $K+N$ assets coincide. Accepting the null or not being able to reject the null hypothesis of spanning would indicate that investors will not be able to attain diversification benefits by investing in the $N$ additional test asset(s). Conversely, rejecting the null hypothesis would imply that, investors will be able to reap diversification benefits by investing in the $N$ test asset(s). ${ }^{10}$ The following joint hypothesis is tested to evaluate whether or not the test assets are spanned:

$$
\text { Null Hypothesis: } \quad \alpha_{\mathrm{i}}=0 ; \mathrm{AND} \sum \beta_{\mathrm{i}}=1
$$

Depending on whether or not a test asset is found to be significant, the following iterative procedure is applied to each of the $N$ asset(s) to determine its

\footnotetext{
${ }^{9}$ We thank an anonymous referee profusely for making this important point.

${ }^{10}$ Details of the mean-variance spanning tests, can be found in DeRoon and Nijman (2001), Kan and Zhou (2001), Chen et al. (2005), Switzer and Fan (2007) and Kan and Zhou (2012) among others.
} 
diversification potential and to evaluate the composition of the benchmark portfolio. When a particular test asset is found to be significant, the test asset is added to the original set of $K$ benchmark assets to form a revised benchmark against which the new test asset is regressed. Conversely, when a particular test asset is found to be insignificant, the benchmark is not revised. For instance, let us assume that we only have two test assets $(N=2)$ and we would like to test the diversification attributes of each asset. We would start our analysis by regressing test asset 1 against a set of $K$ benchmark asset(s):

$$
\begin{aligned}
& \text { TestAsset }_{1}=\alpha_{\mathrm{i}}+\beta_{1}{ }^{*} \text { BenchamarkAsset }(s)+\varepsilon_{i} \\
& \text { Null Hypothesis : } \quad \alpha_{\mathrm{i}}=0 ; \mathrm{AND} \sum \beta_{\mathrm{i}}=1
\end{aligned}
$$

If the null hypothesis is rejected, that is, the test asset is found to be statistically significant, the composition of the benchmark portfolio will need to be revised since the test asset 1 will be added to the benchmark to create a revised benchmark against which the test asset 2 will be regressed. However if the null hypothesis cannot be rejected, the benchmark will not be revised. Let us assume that the null hypothesis is rejected. Then the regression equation takes the following form:

$$
\begin{aligned}
& \text { TestAsset }_{2}=\alpha_{\mathrm{i}}+\beta_{1}{ }^{*}\left[{\text { BenchamarkAsset } \left.(\mathrm{s})+\text { TestAsset }_{1}\right]}\right]+\varepsilon_{i} \\
& \text { Null Hypothesis }: \quad \alpha_{\mathrm{i}}=0 ; \text { AND } \sum \beta_{\mathrm{i}}=1
\end{aligned}
$$

This iterative procedure is continued until the list of $N$ test asset(s) is exhausted. The Wald likelihood ratio test and Lagrange multiplier test statistics are used to test the null hypothesis (See Switzer and Fan (2007)) for an extensive discussion).

Extending the analyses to our study, we test, whether adding each of the real estate property type index to some well known benchmark portfolio provides diversification benefits. Therefore, we regress each of the property type indexes against a set of benchmark assets and test its statistical significance:

$$
\begin{aligned}
& \text { Property-type } e_{i}=\alpha_{\mathrm{i}}+\beta_{1}{ }^{*} \text { BenchamarkAsset }(s)+\varepsilon_{i} \\
& \text { Null Hypothesis }: \alpha_{\mathrm{i}}=0 ; \mathrm{AND} \sum \beta_{\mathrm{i}}=1
\end{aligned}
$$

To evaluate the diversification attributes of the real estate property type portfolios over time, the analyses is conducted over the entire period, the pre-crisis period and the post-crisis period.

\section{Short-Run Analysis: Granger Causality Tests and Impulse Response Function Analysis}

Short-run tests are conducted to evaluate lead-lag relationships and to examine whether and how the interlinkages among the sectors have changed after the onset of the housing crisis. These relationships are evaluated by means of multivariate Granger's causality tests (Granger, 1988) and impulse response function analysis.

The Granger's causality tests analyze short-run causal linkages and are modeled in one of two ways depending on whether the variables are cointegrated or not. If no 
evidence of cointegration is found, causality tests are employed by formulating a VAR similar to Eq. (4):

$$
\Delta X_{t}=\mu+\Gamma_{1} \Delta X_{t-1}+\ldots+\Gamma_{p} \Delta X_{t-p}+\varepsilon_{t}
$$

where $\Delta$ is the difference operator, $X_{t}$ is a $(7 \times 1)$ matrix composed of first differences of the sectoral indices, $\mu$ is a $(7 \times 1)$ vector of constants, $\Gamma_{i}$ is a $(7 \times 7)$ matrix of beta coefficients, $X_{t-i}$ is a $(7 \times 1)$ matrix of lagged endogenous variables and $\varepsilon_{t}$ is a $(7 \times 1)$ matrix of white noise error terms. On the other hand, if the variables are found to be cointegrated, the equation is modelled in the following manner:

$$
\Delta X_{t}=\mu+\Gamma_{1} \Delta X_{t-1}+\ldots+\Gamma_{p} \Delta X_{t-p}+\lambda \hat{e}_{t-1}+\varepsilon_{t}
$$

where $\hat{e}_{t-1}$ is the error correction term and measures how the variables adjust to descrepancies from the long-run equilibrium relationships. To illustrate, when the residential sector is the dependant variable, the above equation can be written as follows:

$$
\begin{aligned}
\Delta \text { LResi }_{t}= & C_{0}+\Sigma_{l=1}^{p} \alpha_{1, l} \Delta \text { LResi }_{t-1}+\ldots+\Sigma_{l=1}^{p} \alpha_{6, l} \Delta \text { LOffice }_{t-1}+\delta_{1} \text { ECT }_{t-1} \\
& +\ldots \delta_{n} \text { ECTn }_{t-1}+\varepsilon_{t}
\end{aligned}
$$

In the above equation, causality of the dependent variable by the independent variables can be observed either through 1) the lagged values of the independent variables $\alpha_{i s}$, or 2) the coefficients $\delta_{i s}$ error correction term(s) (ECT). Thus, the industrial sector would Granger cause the residential sector if either 1) the coefficients on the lagged $\Delta$ Indus variable are jointly significant (that is, the null hypothesis $\alpha_{1,1}=$ $\alpha_{1,2}=\alpha_{1, p}=0$ can be rejected) as calculated by the F-statistic, or 2) the coefficient (of any one) of the error correction term(s) $\delta_{\text {is }}$ is significant as measured by the T-statistic. ${ }^{11}$

Finally, impulse response function (IRF) analyses are conducted to visually compare the transmission of shocks to and from each sector over the pre-crisis and the post-crisis periods and to analyze whether "ripple effects" can be observed across the sectors. This paper uses the definition of ripple effects as postulated in and Ashworth and Parker (1997), Cook (2003) and Clark and Coggin (2009) which states that if shocks originate in one leading market/variable and eventually gets transmitted to others then ripple effect exists. In essence, the IRFs analyze (1) the speed with which a one standard deviation shock in one variable is transmitted to the other variables in the system, (2) the magnitude of these responses, (3) whether the shocks have a permanent or transitory impact, and (4) whether one or more of the sectors can be identified as the "driver" sector from which shocks originate and then ripple across to the remaining sectors.

\footnotetext{
${ }^{11}$ Many studies in the literature have ignored this second potential source of causality that is causality through the ECT(s).
} 


\section{Hypothesis tests}

Based on the foregoing the following hypothesis tests are conducted:

- H1. The property sectors cannot be characterized as unit root or difference stationary processes.

- H2. The property sectors are not tied together in the long-run.

- H3. The 2007-2008 global financial crisis did not have any effect on increasing the level of convergence among the property sectors.

- H4. Certain property sectors cannot be categorized as "independent" sectors that provide greater long-run diversification benefits.

- H5. The results of the spanning regression analysis and cointegration analysis do not yield inconsistent results from a portfolio diversification point of view.

- H6. The property sectors do not affect one another over the short-run.

- H7. Shocks to one sector do not transmit to others over the short-run.

- H8. Certain property types cannot be classified as the "leader" sector from which shocks originate and eventually ripples across to other sectors.

\section{Empirical results}

\section{Unit Root Tests: Univariate Properties of the Sector Indexes}

The results of the unit toot tests are reported in Table 3. The first two columns show the results of the $\mathrm{Ng}$ and Perron (2001) tests and indicate that each real estate sector is an $I(1)$ process. The remaining columns show the results of the Perron (1997), Zivot and Andrews (1992) and Lee and Schwartz (2003) tests for structural breaks. The results indicate evidence in favor of a statistically significant break during the

Table 3 Unit root tests

\begin{tabular}{lllllllll}
\hline Sector & Mza & MSB & Perron & Perron-break & Zivot & Zivot-break & Lsunit & Lsunit Break \\
\hline Residential & 1.21 & 1.11 & $5.84^{*}$ & $2008: 08$ & $4.48^{*}$ & $2008: 10$ & $6.04^{*}$ & $2008: 09$ \\
Health & 1.31 & 1.12 & 4.01 & - & 3.73 & - & 1.66 & - \\
Industrial & 0.02 & 0.72 & $9.44^{*}$ & $2008: 08$ & $8.73^{*}$ & $2008: 10$ & $10.55^{*}$ & $2008: 09$ \\
Lodge-Resort & 4.96 & 0.27 & 4.1 & - & 3.93 & - & 3.71 & - \\
Office & 0.87 & 1.16 & $5.62^{*}$ & $2008: 07$ & $5.08^{*}$ & $2008: 09$ & $6.78^{*}$ & $2008: 09$ \\
Retail & 0.74 & 0.81 & $4.9^{*}$ & $2008: 07$ & $4.62^{*}$ & $2008: 10$ & $7.82^{*}$ & $2008: 09$ \\
Storage & 1.64 & 2.69 & 3.73 & - & 3.74 & - & 2.17 & - \\
\hline
\end{tabular}

Critical values for the $M Z_{\alpha}$ and $M Z_{t}$ statistics obtained from $\mathrm{Ng}$ and Perron (2001) are -17.30 and -2.91 , respectively, at the $5 \%$ level

Critical values for the Perron test (Perron 1997) test is 5.55 at the 5\% level of significance

The critical values for the Lee and Strazicich (2003) test is 3.57 at the 5\% level of significance

The critical values for the Zivot and Andrews (1992) test is 5.08 at the $5 \%$ level of significance

* denotes statistical significance at the $5 \%$ level 
latter part of 2008 (last quarter of 2008) for the residential, industrial, office and retail sectors. For the health, office and storage sector, no evidence of a significant break is found since the test statistics reported is far below the critical value for these indexes. Since evidence of statistically significant breaks are found for many of the series, the data set is broken down and most subsequent analyses are conducted over the entire period (1994-2014), the pre-crisis period (1994-2008) and the post-crisis period (2008-2014) to compare the co-movement among these sectors prior to and after the GFC.

\section{Long-Run Analysis: Multivariate Properties of the Sector Indexes}

The Johansen's cointegration test is implemented to analyze long-run equilibrium relationships among the real estate sectors. Results of the cointegration tests are reported in Table 4 and indicate that over the entire period (1994-2014), the sectors are bound together by six cointegrating vectors (Panel A). However, over the precrisis period (1994-2008), they are bound together by only five cointegrating vectors (Panel B). Although not shown for brevity purposes, the findings also indicate that the sectors are bound together by six cointegrating vectors over the post-crisis (2008-2014) period, results that are fully consistent with the entire sample analysis. ${ }^{12}$ For each sub-period analyses, both the $\lambda_{\text {Trace }}$ and the $\lambda_{\text {Max }}$ statistics are compared to their corresponding critical values from OsterwaldLenum (1992) and yield consistent results.

Next, exclusion test are conducted to evaluate whether each of the variables is indeed part of the cointegrating relationships, or if some can be excluded. Results of the exclusion tests also reported in Table 4 (Panels A and B) show that each sector is part of the cointegrating relationships since the null hypothesis that $\beta_{i}=0$ is rejected during each sub-period suggesting that each sector belong in the long-run relationships.

In summary, the findings of the long-run analyses indicate that the sectors are bound together by six cointegrating vectors (CIVs) after the crisis but only five CIVs before the crisis. As noted in Stock and Watson (1988), Bernard and Durlauf (1995) and Haug et al. (2000), this suggests that the sectors have become fully integrated after the crisis since $r=n-1$ cointegrating vectors but were only partially integrated before the crisis since $1 \leq r \leq n-1$ evidence indicative of contagious behavior. These findings of increased convergence among the real estate sectors after the GFC is consistent with the contagion literature that suggest spillover of shocks across all sectors of the economy in the wake of a major economic downturn.

\section{Spanning regression analyses}

As mentioned, earlier, spanning tests are implemented to analyze the diversification benefits of incorporating each real estate property type index to a set of benchmark assets. We begin our analyses by using S\&P 500 total return index and the Russell 2000 total return index as the benchmark portfolio. ${ }^{13}$ We then test each property-type

\footnotetext{
12 These results are available upon request.

${ }^{13}$ Data have been provided by CEIC and the FRED.
} 
Table 4 Cointegration and exclusion test results

\begin{tabular}{|c|c|c|c|c|c|c|c|}
\hline \multirow{2}{*}{$\begin{array}{l}\text { Panel A } \\
\mathrm{H} 0:\end{array}$} & \multicolumn{7}{|l|}{$1994-2014$} \\
\hline & 0 & 1 & 2 & 3 & 4 & 5 & 6 \\
\hline$\lambda_{\text {Trace }}$ test $^{a}$ & $r=0$ & $r \leq 1$ & $r \leq 2$ & $r \leq 3$ & $r \leq 4$ & $r \leq 5$ & $r \leq 6$ \\
\hline Trace CV & 131.7 & 102.14 & 76.07 & 53.12 & 34.91 & 19.96 & 9.24 \\
\hline$\lambda_{\text {Max }}$ test $^{a}$ & $r=0$ & $r=1$ & $r=2$ & $r=3$ & $r=4$ & $r=5$ & $r=6$ \\
\hline Max CV & 46.45 & 40.3 & 34.4 & 28.14 & 22 & 15.67 & 9.24 \\
\hline Trace statistic & $203.79 *$ & $148.65^{*}$ & $100.08^{*}$ & $63.25^{*}$ & $35.56^{*}$ & $17.96^{*}$ & 4.41 \\
\hline Max statistic & $85.38^{*}$ & $47.92 *$ & $34.74^{*}$ & $22.86^{*}$ & $17.59^{*}$ & 9.17 & 0.12 \\
\hline Exclusion Test & Residential & Health & Industrial & Lodge-Resort & Office & Retail & Storage \\
\hline$\beta_{i=0}{ }^{b}$ & $47.23^{*}$ & $55.08^{*}$ & $75.78^{*}$ & $17.59^{*}$ & $68.09^{*}$ & $68.95 *$ & $44.01 *$ \\
\hline Panel B & 1994-2008 & & & & & & \\
\hline HO: & 0 & 1 & 2 & 3 & 4 & 5 & 6 \\
\hline$\lambda_{\text {Trace }}$ test $^{a}$ & $r=0$ & $r \leq 1$ & $r \leq 2$ & $r \leq 3$ & $r \leq 4$ & $r \leq 5$ & $r \leq 6$ \\
\hline Trace CV & 131.7 & 102.14 & 76.07 & 53.12 & 34.91 & 19.96 & 9.24 \\
\hline$\lambda_{\text {Max }} t_{e s}{ }^{a}$ & $r=0$ & $r=1$ & $r=2$ & $r=3$ & $r=4$ & $r=5$ & $r=6$ \\
\hline Max CV & 46.45 & 40.3 & 34.4 & 28.14 & 22 & 15.67 & 9.24 \\
\hline Trace statistic & $217.79 *$ & $132.41 *$ & $84.49^{*}$ & $49.75^{*}$ & $26.89^{*}$ & 9.29 & 0.12 \\
\hline Max statistic & $55.15^{*}$ & $48.57^{*}$ & $36.83^{*}$ & $27.69^{*}$ & $17.6^{*}$ & $13.55^{*}$ & 4.41 \\
\hline Exclusion Test & Residential & Health & Industrial & Lodge-Resort & Office & Retail & Storage \\
\hline$\beta_{i=0^{b}}$ & $28.17^{*}$ & $34.74 *$ & $65.2 *$ & $16.55^{*}$ & $35.02 *$ & $56.7 *$ & $21.13^{*}$ \\
\hline
\end{tabular}

$*$ and $* *$ denotes significance at the $5 \%$ and $10 \%$ levels respectively

a.The null hypothesis is $H_{0}$ which tests for the number of cointegrating vectors (designated by $r$ ) and is given by the $\lambda_{\text {Trace }}$ and the $\lambda_{\text {Max }}$ test statistics respectively. The critical values have been obtained from OsterwaldLenum (1992)

b. Real estate sector $i$ can be excluded from the cointegration space. The test statistics a and $\mathrm{b}$ are distributed $\chi^{2}(r) \times[n-(n-m)]$ where $n$ is the number of variables in the VAR and $m$ is the number of restrictions in the system

index against this benchmark, in a descending order based on market capitalization as reported in Table $1 .{ }^{14}$ Since the retail index has the highest market capitalization, our first regression involves regressing the returns of the retail index against the benchmark assets:

$$
\begin{aligned}
& \text { Retail }_{i}=\alpha_{\mathrm{i}}+\beta_{1}{ }^{*} \mathrm{~S} P 500+\beta_{2}{ }^{*} \mathrm{R} u \text { ssel } 2000+\varepsilon_{i} \\
& \text { Null Hypothesis : } \quad \alpha_{\mathrm{i}}=0 ; \mathrm{A} N D \beta_{1}+\beta_{2}=1
\end{aligned}
$$

Table 5, Panels A, B and C reports the results of the spanning tests for the entire period, the pre-crisis period and the post-crisis period. As indicated in Panel A, over the entire period, the retail index is found to be significant in the spanning regression and hence the benchmark portfolio is revised to incorporate the retail index against we regress the new test asset which is the residential property index.

\footnotetext{
${ }^{14}$ See for instance Chen et al. (2005) and Switzer and Fan (2007) among others who used similar benchmark and who perform the spanning regressions in a similar fashion.
} 
Table 5 Portfolio Spanning Tests: SP500 and Russel 2000 as the basic benchmark

\begin{tabular}{|c|c|c|c|c|}
\hline Panel A & Whole Period & & & \\
\hline Case & Test asset & Benchmark assets & p-value(Wald) & p-value (LM) \\
\hline 1 & Retail & SP500 and R2000 & $0.00 * *$ & $0.00 * *$ \\
\hline 2 & Residential & SP500, R2000 and Retail & $0.00 * *$ & $0.00 * *$ \\
\hline 3 & Healthcare & SP500, R2000, Retail and Residential & 0.71 & 0.68 \\
\hline 4 & Office & SP500, R2000, Retail, Residential & 0.31 & 0.29 \\
\hline 5 & Lodging/Resorts & SP500, R2000, Retail, Residential & $0.00 * *$ & $0.00 * *$ \\
\hline 6 & Self Storage & $\begin{array}{l}\text { SP500, R2000, Retail, Residential, } \\
\text { and Lodge }\end{array}$ & $0.00 * *$ & $0.00 * *$ \\
\hline 7 & Industrial & $\begin{array}{l}\text { SP500 and R2000, Retail, Residential, } \\
\text { Lodge, and Storage }\end{array}$ & $0.00 * *$ & $0.00 * *$ \\
\hline Panel B & Pre-crisis & & & \\
\hline Case & Test asset & Benchmark assets & p-value(Wald) & p-value (LM) \\
\hline 1 & Retail & SP500 and R2000 & $0.00 * *$ & $0.00 * *$ \\
\hline 2 & Residential & SP500, R2000 and Retail & $0.00 * *$ & $0.00 * *$ \\
\hline 3 & Healthcare & SP500, R2000, Retail and Residential & $0.00 * *$ & $0.00 * *$ \\
\hline 4 & Office & $\begin{array}{l}\text { SP500, R2000, Retail, Residential } \\
\text { and Health }\end{array}$ & $0.00 * *$ & $0.00 * *$ \\
\hline 5 & Lodging/Resorts & $\begin{array}{l}\text { SP500, R2000, Retail, Residential, } \\
\text { Health and Office }\end{array}$ & $0.00 * *$ & $0.00 * *$ \\
\hline 6 & Self Storage & $\begin{array}{l}\text { SP500, R2000, Retail, Residential, } \\
\text { Health, Office and Lodge }\end{array}$ & $0.00 * *$ & $0.00 * *$ \\
\hline 7 & Industrial & $\begin{array}{l}\text { SP500, R2000, Retail, Residential, } \\
\text { Health, Office and Lodge }\end{array}$ & $0.00 * *$ & $0.00 * *$ \\
\hline Panel C & Crisis & & & \\
\hline Case & Test asset & Benchmark assets & p-value(Wald) & p-value (LM) \\
\hline 1 & Retail & SP500 and R2000 & $0.00 * *$ & $0.00 * *$ \\
\hline 2 & Residential & SP500, R2000 and Retail & $0.00 * *$ & $0.00 * *$ \\
\hline 3 & Healthcare & $\begin{array}{l}\text { SP500, R2000, Retail and } \\
\quad \text { Residential }\end{array}$ & $0.00 * *$ & $0.00 * *$ \\
\hline 4 & Office & $\begin{array}{l}\text { SP500, R2000, Retail, Residential } \\
\text { and Health }\end{array}$ & $0.00 * *$ & $0.00 * *$ \\
\hline 5 & Lodging/Resorts & $\begin{array}{l}\text { SP500, R2000, Retail, Residential, } \\
\text { Health and Office }\end{array}$ & 0.56 & 0.89 \\
\hline 6 & Self Storage & $\begin{array}{l}\text { SP500, R2000, Retail, Residential, } \\
\text { Health and Office }\end{array}$ & $0.00 * *$ & $0.00 * *$ \\
\hline 7 & Industrial & $\begin{array}{l}\text { SP500, R2000, Retail, Residential, } \\
\text { Health, Office and Storage }\end{array}$ & 0.38 & 0.26 \\
\hline
\end{tabular}

$*$ and $* *$ denotes significance at the $5 \%$ and $10 \%$ levels respectively

Residential $_{i}=\alpha_{\mathrm{i}}+\beta_{1}{ }^{*} \mathrm{~S} P 500+\beta_{2}{ }^{*} \mathrm{R} u$ ssel2000 $+\beta_{3}{ }^{*}$ Retail $+\varepsilon_{i}$ Null Hypothesis : $\quad \alpha_{\mathrm{i}}=0 ; \mathrm{AND} \beta_{1}+\beta_{2}+\beta_{3}=1$

This iterative procedure is continued until we exhaust our list of property-type indexes, over the entire period in each of the sub-periods. 
Overall, the results of the spanning tests can be summarized as follows: Over the entire period, each of the indexes is found to be significant except for the healthcare and office indexes which are found to be insignificant. Over the pre-crisis period, each of the property type indexes is found to be significant while over the post-crisis period, lodging and industrial are found to be insignificant. These results indicate that other than the healthcare and office property types each of the real estate sub-sectors offered diversification benefits over the entire period; each of the property type indexes offered diversification benefits over the pre-crisis period, while except for the lodging-resort and industrial indexes each of the real estate sub-sectors offered diversification benefits over the crisis period.

Due to the fact that research has suggested that the results of the spanning tests may be sensitive to the choice of benchmark asset utilized and the time period being analyzed, we re-run all tests by incorporating long-term Government bonds and Moody's AAA corporate bonds ${ }^{15}$ to the set of benchmark assets to analyze whether the results are similar to or different from those found when only stocks were part of the benchmark assets. ${ }^{16}$ The results of this analysis are presented in Table 6, Panels A, B and $\mathrm{C}$. The findings indicate that each property type index is significant over the entire period, but that industrial and self storage are insignificant over the pre-crisis period and that office and lodging are insignificant over the crisis-results that are not consistent to those found when only stocks were part of the benchmark assets. Thus the results of our spanning tests confirm earlier studies that had demonstrated that traditional spanning tests may be sensitive to the choice of benchmarks assets used and the time horizon analyzed (Chen et al. 2005, Chiang and Lee 2007 and Switzer and Fan 2007 among others).

\section{Spanning Analyses Versus Cointegration Results: Discrepancy in Results}

As illustrated earlier, the results and the implications of the spanning regression analysis are not consistent to those of the cointegration analysis. On the one hand, the spanning regression results had indicated that diversification benefits can be reaped across a host of property types across time, while the results of the cointegration tests revealed that the property types are integrated and fully converging over time and thus diversification benefits cannot be reaped across these markets since they trend together in the long-run. ${ }^{17}$ The difference in results is expected since there are some inherent problems associated with regression analysis that makes it unsuitable for analyzing long-term relationships.

First, regression analysis utilizes returns information and neglects information contained in levels data. This is a very serious problem since any decisions based on the differenced (returns) data will be unreliable especially over the long-run as it

\footnotetext{
${ }^{15}$ Data have been provided by CEIC and the FRED.

${ }^{16}$ See for instance Chen et al. (2005) and Chiang and Lee (2007) among others who use similar benchmark.

${ }^{17}$ Since the results of the spanning tests yielded inconclusive results when stocks and bonds were added to the benchmark, we evaluate, whether or how the addition of stocks and bonds affect the cointegration test results. Thus, separate cointegration tests are conducted to analyze the long-run linkages among financial assets and property sectors. The results indicate that the number of cointegrating vectors increased when stock market indexes are added and even more so when bond market indexes are included. However, the addition of stock and bond market indexes does not change the inference or the implications of the cointegration results from a portfolio diversification point of view. These results are not reported due to brevity purposes but are available upon request.
} 
Table 6 Portfolio Spanning Tests: SP500, Russel 2000, T-Bond and Corp-Bond as the basic benchmark

\begin{tabular}{|c|c|c|c|c|}
\hline Panel A & Whole Period & & & \\
\hline Case & Test asset & Benchmark assets & p-value(Wald) & p-value (LM) \\
\hline 1 & Retail & SP500, R2000, T-Bond and Corp-Bond & $0.00^{* *} *$ & $0.00 * *$ \\
\hline 2 & Residential & SP500, R2000, T-Bond, Corp-Bond and Retail & $0.00 * *$ & $0.00 * *$ \\
\hline 3 & Healthcare & $\begin{array}{l}\text { SP500, R2000, T-Bond, Corp-Bond, Retail } \\
\text { and Residential }\end{array}$ & $0.00 * *$ & $0.00 * *$ \\
\hline 4 & Office & $\begin{array}{l}\text { SP500, R2000, T-Bond, Corp-Bond, Retail } \\
\text { and Residential }\end{array}$ & $0.00 * *$ & $0.00 * *$ \\
\hline 5 & Lodging/Resorts & $\begin{array}{l}\text { SP500, R2000, T-Bond, Corp-Bond, Retail } \\
\text { and Residential }\end{array}$ & $0.00^{* *}$ & $0.00 * *$ \\
\hline 6 & Self Storage & $\begin{array}{l}\text { SP500, R2000, T-Bond, Corp-Bond, Retail, } \\
\text { Residential and Lodge }\end{array}$ & $0.00 * *$ & $0.00 * *$ \\
\hline 7 & Industrial & $\begin{array}{l}\text { SP500, R2000, T-Bond, Corp-Bond, Retail, } \\
\text { Residential Lodge and Storage }\end{array}$ & $0.00 * *$ & $0.00 * *$ \\
\hline Panel B & Pre-crisis & & & \\
\hline Case & Test asset & Benchmark assets & p-value(Wald) & p-value (LM) \\
\hline 1 & Retail & SP500, R2000, T-Bond and Corp-Bond & $0.00 * *$ & $0.00 * *$ \\
\hline 2 & Residential & SP500, R2000, T-Bond, Corp-Bond and Retail & $0.00 * *$ & $0.00 * *$ \\
\hline 3 & Healthcare & $\begin{array}{l}\text { SP500, R2000, T-Bond, Corp-Bond, Retail } \\
\text { and Residential }\end{array}$ & $0.00 * *$ & $0.00 * *$ \\
\hline 4 & Office & $\begin{array}{l}\text { SP500, R2000, T-Bond, Corp-Bond, Retail } \\
\text { and Residential }\end{array}$ & $0.00 * *$ & $0.00 * *$ \\
\hline 5 & Lodging/Resorts & $\begin{array}{l}\text { SP500, R2000, T-Bond, Corp-Bond, Retail, } \\
\text { Residential and Office }\end{array}$ & $0.00 * *$ & $0.00 * *$ \\
\hline 6 & Self Storage & $\begin{array}{l}\text { SP500, R2000, T-Bond, Corp-Bond, Retail, } \\
\text { Residential, Office and Lodge }\end{array}$ & 0.34 & 0.48 \\
\hline 7 & Industrial & $\begin{array}{l}\text { SP500, R2000, T-Bond, Corp-Bond, Retail, } \\
\text { Residential, Office and Lodge }\end{array}$ & 0.14 & 0.12 \\
\hline Panel C & Crisis & & & \\
\hline Case & Test asset & Benchmark assets & p-value(Wald) & p-value (LM) \\
\hline 1 & Retail & SP500, R2000, T-Bond and Corp-Bond & $0.00 * *$ & $0.00 * *$ \\
\hline 2 & Residential & SP500, R2000, T-Bond, Corp-Bond and Retail & $0.00 * *$ & $0.00 * *$ \\
\hline 3 & Healthcare & $\begin{array}{l}\text { SP500, R2000, T-Bond, Corp-Bond, Retail } \\
\text { and Residential }\end{array}$ & $0.00 * *$ & $0.00 * *$ \\
\hline 4 & Office & $\begin{array}{l}\text { SP500, R2000, T-Bond, Corp-Bond, Retail, } \\
\text { Residential and Health }\end{array}$ & 0.16 & 0.13 \\
\hline 5 & Lodging/Resorts & $\begin{array}{l}\text { SP500, R2000, T-Bond, Corp-Bond, Retail, } \\
\text { Residential, Health }\end{array}$ & 0.13 & 0.11 \\
\hline 6 & Self Storage & $\begin{array}{l}\text { SP500, R2000, T-Bond, Corp-Bond, Retail, } \\
\text { Residential, Health and Lodge }\end{array}$ & $0.00 * *$ & $0.00 * *$ \\
\hline 7 & Industrial & $\begin{array}{l}\text { SP500, R2000, T-Bond, Corp-Bond, Retail, } \\
\text { Residential, Health, Lodge and Storage }\end{array}$ & $0.00 * *$ & $0.00 * *$ \\
\hline
\end{tabular}

$*$ and $* *$ denotes significance at the $5 \%$ and $10 \%$ levels respectively

excludes the long-run information that is an inherent part of the levels (raw price) data (Alexander (2001)). Second, related research has suggested detrending the series or 
converting them to first differences, leads to misspecifications (see Kasa (1992) and Alexander (2001)), such that regression applications using returns of financial/macroeconomic indices suffer from misspecification error.

Due to the potential issues associated with regression analysis, we implement cointegration technique and emphasize on the results of the cointegration tests throughout the paper to identify the diversification attributes of the property sectors over the long run. As noted by several authors', cointegration analysis is very effective in analyzing the long-term dynamics within a multivariate system and thus investment strategies based on cointegration will be effectual especially in the longrun. ${ }^{18}$ Moreover, some relatively recent research by Alexander (2001) and Alexander and Dimitriu (2005), has also suggested that cointegration based models for index tracking consistently over perform traditional tracking error models (Roll, 1992) over different time periods, over risky market conditions and even after transactions costs are accounted for.

\section{Short-Run Analysis: Granger's Causality Tests and Impulse Response Analysis}

Multivariate Granger's causality tests as advocated in Granger (1988) and impulse response function analysis are used to evaluate short-run interactions among the sectors. Result of the causality tests presented in Table 7 indicate significant lead-lag relationships and bi-directional causality running to and from each sector under consideration. It is important to note that, in cases when the coefficients of the lagged independent variables are not significant, the relationships are caused by evaluating the statistical significance of the error-correction terms. These results are consistent with the long-run results that had indicated that shocks propagated across all sectors even in the short-run.

Next, impulse response functions are created to further scrutinize the short-run interactions among the sectors and to analyze whether ripple effects can be observed. The IRF graphs for the pre-crisis and post-crisis periods are presented in Fig. 3 which depicts the response of each sector to a one standard deviation shock to the remaining sectors over the two sub-periods. The graphs on the left hand side show the response of shocks over the pre-crisis period while the figures on the right hand side show the response during the post-crisis period. For instance, Fig. 3(a) shows the response of the residential sector to a one standard deviation shock to the remaining sectors over the pre-crisis period, Fig. 3(b) shows the response of the residential over the post-crisis period while Fig. 3(c through $\mathrm{n}$ ) shows the response of shocks to and from the remaining sectors. Moreover, for comparative purposes, Fig. 3(o and p) depict the response of the residential sector to a one standard deviation shock in the remaining sectors.

A couple of interesting observations can be made by scrutinizing the IRF graphs: First, a comparison of the pre-crisis and post-crisis periods reveal that over the pre-crisis period, shocks die out completely at the end of approximately 16 months but over the post-crisis period, shocks are long-lasting persisting more than 22 months. Second, it is quite clear that shocks from the residential sector influences the remaining sectors quite

\footnotetext{
${ }^{18}$ Granger and Newbold (1974), Enders (1995), Hamilton (1994), Hendry (1995), Alexander (2001), Phylaktis and Ravazzolo (2005), Syriopoulos (2006) and Alexakis (2010).
} 
Table 7 Granger's Causality Tests

\begin{tabular}{|c|c|c|c|c|c|c|c|c|c|c|c|c|c|}
\hline Indp.Vars $\rightarrow$ & $\Delta$ Resi $_{t}$ & $\Delta$ Health & SIndus & $\Delta$ LodgeRes $_{t}$ & $\Delta$ Office $_{t}$ & $\Delta$ Retail $_{t}$ & $\Delta$ Storage $_{i}$ & CIV1 & CIV2 & CIV3 & CIV4 & CIV5 & CIV6 \\
\hline \multicolumn{14}{|l|}{ Dep.Vars $\downarrow$} \\
\hline$\Delta$ Resi $_{t}$ & - & $0.09 *$ & 0.00 ** & $0.01 * *$ & 0.66 & 0.96 & 0.28 & 0.55 & 0.35 & 0.36 & $0.09^{*}$ & $0.00 * *$ & $0.00 *$ \\
\hline$\Delta$ Health & 0.66 & - & $0.01^{\text {*** }}$ & 0.11 & 0.66 & 0.86 & 0.28 & 0.70 & 0.70 & 0.64 & 0.90 & $0.00^{* * *}$ & $0.00^{* * *}$ \\
\hline$\Delta I n d u s_{t}$ & 0.99 & $0.04 * *$ & - & $0.01 * *$ & $0.03^{* *}$ & 0.48 & 0.13 & 0.55 & $0.10^{*}$ & 0.24 & 0.66 & $0.00^{* * *}$ & $0.00^{* * *}$ \\
\hline$\Delta$ Lodge $\operatorname{Re} s_{t}$ & 0.33 & 0.54 & $0.00 * *$ & - & 0.90 & 0.85 & $0.01 * *$ & 0.36 & 0.35 & 0.79 & $0.09^{*}$ & $0.00 * *$ & $0.00^{* * *}$ \\
\hline$\Delta$ Office $_{t}$ & 0.17 & $0.03 * *$ & $0.00^{* * *}$ & $0.01 * *$ & - & 0.98 & 0.12 & 0.33 & 0.83 & 0.41 & 0.34 & $0.00 * *$ & $0.00^{* * *}$ \\
\hline$\Delta$ Retail $_{t}$ & 0.35 & 0.15 & 0.00 ** & $0.01 * *$ & 0.38 & 0.99 & - & 0.23 & 0.99 & 0.49 & 0.46 & $0.00 * *$ & $0.00^{* * *}$ \\
\hline$\Delta$ Storage $_{t}$ & 0.16 & 0.12 & $0.00^{* * *}$ & $0.04 * *$ & 0.81 & 1.00 & 0.30 & - & 0.13 & 0.81 & 0.54 & $0.00^{* * *}$ & $0.00^{* * *}$ \\
\hline
\end{tabular}

Abbreviations: Resi-Residential; Indus-Industrail; LodgeRes-Lodging Resort

$\Delta$ denotes the difference operator

Summary of causal relationships: $\Delta$ Housing $\Leftrightarrow \Delta$ each sectors

$*$ and $* *$ denotes statistical significance at the $5 \%$ and the $1 \%$ levels respectively

profoundly (Fig. 3a and b) but in comparison, the residential sector is least affected by shocks emanating from any other sector (Fig. 30 and p): A one standard deviation of shock to the residential sector induces a response of on average 0.5 to 0.8 units to the remaining sectors while a one standard deviation shock to the remaining sectors induces a response of only on average 0.005 to at most 0.016 units to the residential sector in each sub-period. These findings imply that the residential sector is the dominant sector which is highly exogenous such that shocks originate first in the residential sector and then ripples across to all the remaining sectors (Clark and Coggin $(2009,2011)$ and Ashworth and Parker (1997)). These results extend the literature by identifying the "source" of trends across U.S. real estate sectors.

\section{Conclusion}

The study explores the impact of the housing crisis on the nature of dynamic linkages among seven key real estate sectors including residential, health, storage, lodge-resort, retail, office, and industrial. Using the dataset provided by the European Public Real Estate Association (EPRA) and the National Association of Real Estate Investment Trusts (NAREIT) and analyzing the sectors over the period beginning January 1994 and ending December 2014, the results can be summarized as follows:

A number of tests indicate that each real estate sector can be characterized as stochastic unit root processes. Moreover, structural break tests reveal evidence of statistically significant breaks towards the end of 2008 for the vast majority of sectors under consideration. Hence for most subsequent analyses, the dataset is broken down and analyzed over the pre-crisis period (1994-2008) and the post-crisis periods (20082014) respectively to understand the impact of the GFC on these real estate sectors.

Long-run results indicate that the sectors are tied together by a greater number of cointegrating vectors after the crisis in comparison to the pre-crisis period implying contagion from macro-economic shocks intensified only after the housing crisis. Moreover, each sector is part of the cointegrating vectors over the entire period and during each sub-period suggesting that none can be excluded.

Short-run causality tests reveal significant lead-lag relationships and bi-directional causality running to and from each sector. In addition, impulse response function 
Impulse response function analysis

(a) Plot of responses to Residential (Pre)-crisis

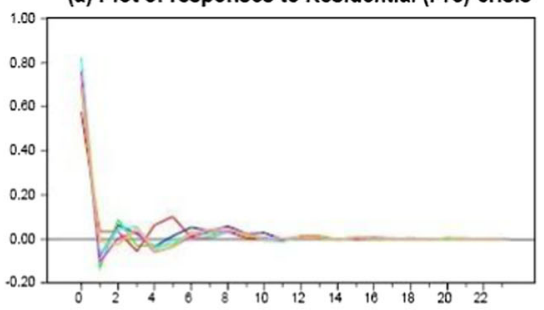

(c)Plot of responses to Health (Pre)-crisis

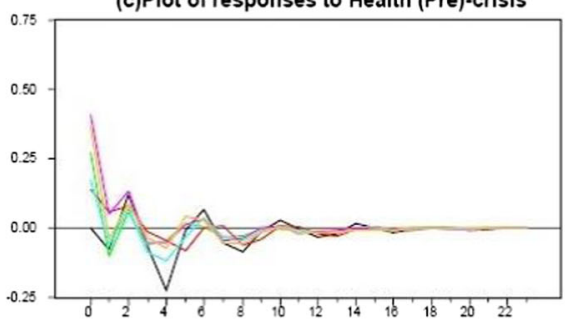

(e) Plot of responses to Industrial (Pre)-crisis

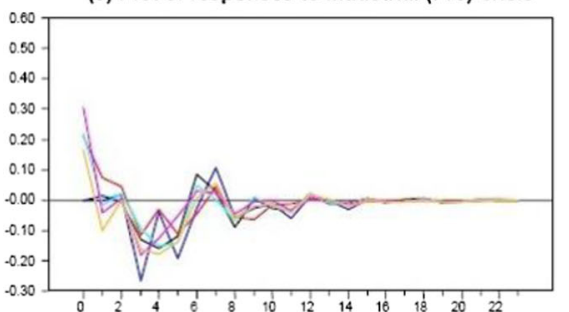

- RESIDENTIAL INDUS

- LODGE RESORT

(b) Plot of responses to Residential (Post)-crisis

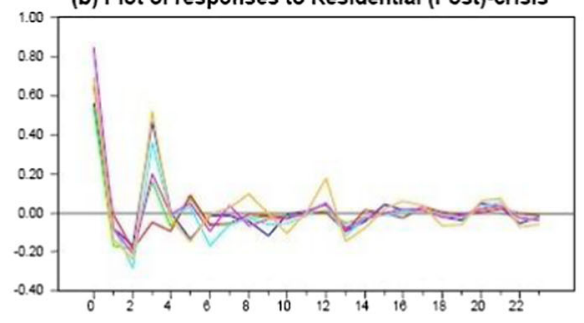

(d) Plot of responses to Health (Post)-crisis

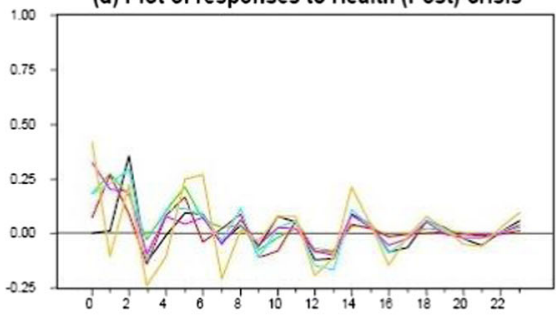

(f) Plot of responses to Industrial (Post)-crisis

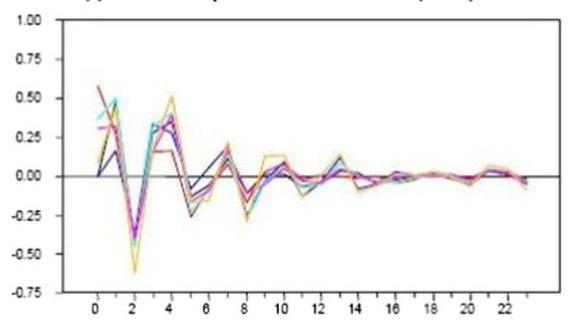

OFFICE

STORAGE

Fig. 3 Note: The figure depicts the response of each sector from shocks emanating from the remaining sector both before and after the housing crisis. For instance Fig. 3a. portrays the response of all sectors to a one standard deviation shock to the residential sector prior to the crisis while Fig. 3b, shows the response of all sectors to a one standard deviation shock to the residential sector during/after crisis and so on and so forth. Figure 3k, portrays the response of all sectors to a one standard deviation shock to the retail sector prior to the crisis while Fig. 31, shows the response of all sectors to a one standard deviation shock to the retail sector during/after crisis and so on and so forth. And finally, Fig. 3o and p show the response of the residential sector to a one standard deviation shock to each remaining sector

analyses results suggest that over the post-crisis period, shocks from one sector had a much more profound and persistent impact on the others, lasting for more than 22 months. In contrast, during the pre-crisis period, shocks from one sector do not affect the others with a similar magnitude and die out completely at the end of approximately 16 months. This indicates that shocks had a much more severe and permanent impact during the post-crisis period in comparison to the pre-crisis period findings consistent with the long-run analyses.

The IRF analyses also indicate that shocks to the residential sector influence the other sectors quite profoundly but that the residential sector is not affected reciprocally: 
(g) Plot of responses to Lodge-Resort (Pre)-crisis

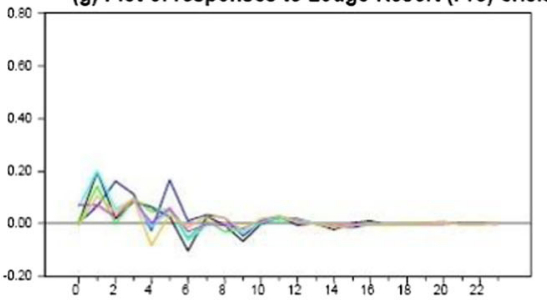

(i) Plot of responses to Office (Pre)-crisis

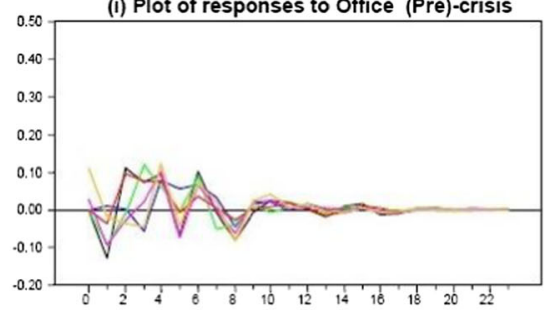

(k) Plot of responses to Retail (Pre)-crisis

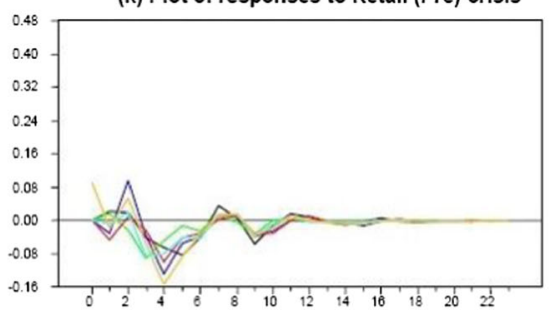

(m) Plot of responses to Storage (Pre)-crisis

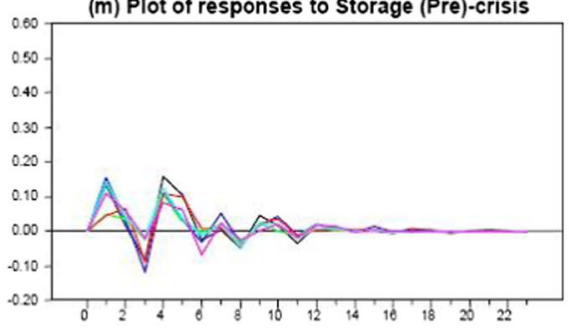

(o) Plot of responses of Residential (Pre)-crisis

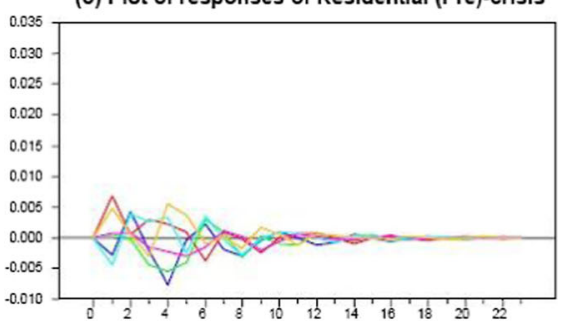

(h) Plot of responses to Lodge-Resort (Post)-crisis
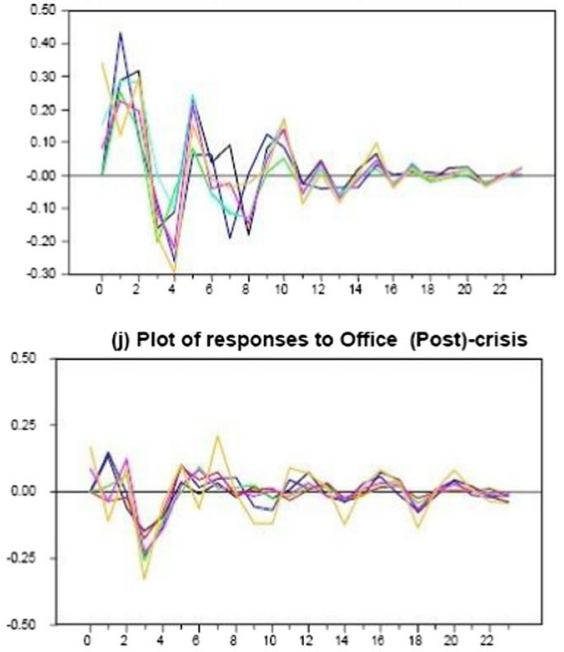

(I) Plot of responses to Retail (Post)-crisis

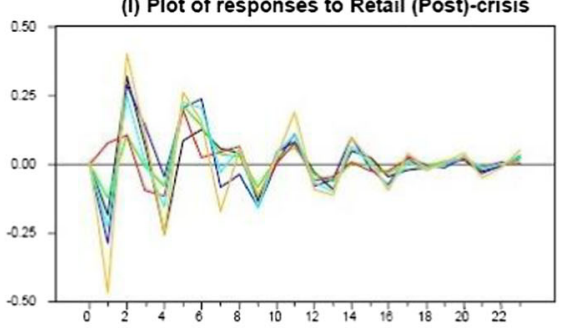

(n) Plot of responses to Storage (Post)-crisis

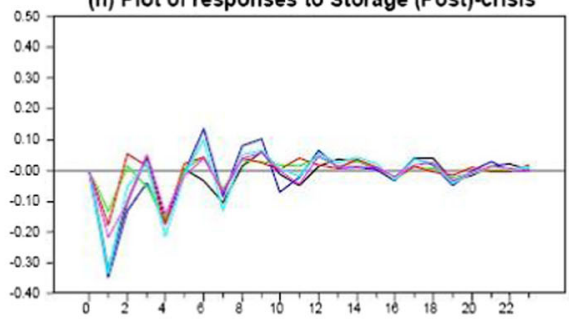

(p) Plot of responses of Residential (Post)-crisis

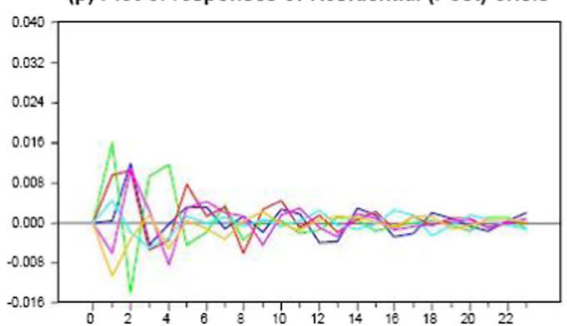

Fig. 3 continued. 
A one standard deviation shock to the residential sector induces a response of 0.5 to 0.8 units to the other sectors while a one standard deviation shock to the remaining sectors induces a response of only on average 0.005 to at most 0.016 units to the residential sector in both sub-periods.

The finding that shocks to the residential sector affects each remaining sectors quite profoundly and persistently but that the residential sector does not react reciprocally imply that the residential sector is the dominant sector which is highly exogenous such that shocks originate first in the residential sector and then ripples across to all the remaining sectors.

The overall findings of this study have crucial long-run and short-run implications from a portfolio diversification point of view. Since the sectors have become fully integrated over time, the results imply that little gain in risk reduction can be achieved by diversifying across sectors, especially over the long-run, since shocks to one sector spills over and affects the remaining sectors. Moreover, the finding that the level of integration increased during the crisis implies that diversification benefits are further eroded during times of economic turmoil and chaos-when investors needed it the most. Short-run results indicate that the residential sector is the highly exogenous driving force such that shocks originate first in the residential sector and then propagate to the others. These results are quite reasonable since as witnessed during the GFC, the residential market played a critical role and contributed to the downfall of the entire economy.

The findings of the study findings could be useful to active investors in allocating among real estate sectors. Moreover, the finding that the residential sector is the "leader" sector will be critically important to regulators and policymakers since it implies that trends and patterns in the residential property sector can be used to forecast the movements in the remaining real estate sectors. Thus, policymakers should pay close attention to the residential property sector to potentially avoid real estate related crises in the future.

\section{References}

Addae-Dapaah, K., \& Yong, C. C. (2000). Diversification of real estate investment in the Asia- Pacific region. Pacific Rim Property Research Journal, 6, 31-45.

Alexander, C. (2001). Market models: A guide to financial data analysis. New York: J. Wiley and Sons.

Alexakis, C. (2010). Long-run relations among equity indices under different market conditions: Implications on the implementation of statistical arbitrage strategies. Journal of International Financial Markets, Institutions \& Money, 20, 389-403.

Alexander, C., \& Dimitriu, A. (2005). Indexing, cointegration and equity market regimes. International Journal of Finance and Economics, 10, 1-19.

Ang, A., Hodrick, B., Xing, Z., \& Zhang, X. (2006). The cross-section of volatility and expected returns. Journal of Finance, 63, 259-299.

Ang, A., Hodrick, B., Xing, Z., \& Zhang, X. (2009). High idiosyncratic volatility and low returns. Journal of Financial Economics, 91, 1-23.

Ashworth, J., \& Parker, S. C. (1997). Modelling regional house prices in the UK. Scottish Journal of Political Economy, 44, 225-246.

Bates, L. J., Giaccotto, C., \& Santerre, R. E. (2015). Is the real estate sector more responsive to economy-wide or housing market conditions? An exploratory analysis. Journal of Real Estate Finance and Economics, $51,541-554$.

Bernard, A., \& Durlauf, S. (1995). Convergence in international output. Journal of Applied Economics, 10, $1072-1085$. 
Blitz, D., Pang, J., \& Van Vliet, P. (2013). The volatility effect in emerging markets. Emerging Markets Review, 16, 31-45.

Case, B., Goetzmann, W., Rouwenhorst, K.G. (2000). Global real estate markets cycles and fundamentals. NBER Working Paper Series Paper No. 7566.

Chan, K. F., Treepongkaruna, S., Brooks, R., \& Gray, S. (2011). Asset market linkages, Evidence from financial, commodity and real estate assets. Journal of Banking \& Finance, 35, 1415-1426.

Chen, H., Ho, K., Lu, C., \& Wu, C. (2005). An asset allocation perspective of real estate: The case of real estate investment trusts. Journal of Portfolio Management, 32, 46-55.

Chiang, K., \& Lee, K. M. N. (2007). Spanning tests on public and private real estate. Journal of Real Estate Portfolio Management, 13, 7-15.

Chiou, W. P. (2009). Benefits of international diversification with investment constraints: An over-time perspective. Journal of Multinational Financial Management, 19, 93-110.

Clark, S. P., \& Coggin, T. D. (2009). Trends, cycles and convergence in U.S. regional house prices. Journal of Real Estate Finance and Economics, 39, 264-283.

Clark, S. P., \& Coggin, T. D. (2011). Was there a U.S. house price bubble? An econometric analysis using national and regional panel data. The Quarterly Review of Economics and Finance, 51, 189-200.

Cook, S. (2003). The convergence of regional house prices in the UK. Urban Studies, 40, 2285-2294.

Darrat, A. F., \& Glascock, J. L. (1993). On the real estate market efficiency. The Journal of Real Estate Finance and Economics, 7, 55-72.

DeRoon, F. A., \& Nijnian, T. E. (2001). Testing for mean-variance spanning, A survey. Journal of Empirical Finance, 8, 111-155.

Dickey, D., \& Fuller, W. A. (1979). Distribution of the estimate for autoregressive time series with a unit root. Journal of the American Statistical Association, 74, 427-431.

Dickey, D. A., \& Fuller, W. A. (1981). Likelihood ratio statistics for autoregressive time series with a unit root. Econometrica, 49, 1057-1072.

Dooley, M., \& Hutchison, M. (2009). Transmission of the U.S. subprime crisis to emerging markets, Evidence on the decoupling recoupling hypothesis. Journal of International Money and Finance, 28, 1331-1349.

Durlauf, S. N. (1989). Output persistence, economic structure, and the choice of stabilization policy. Brookings Papers in Economic Activity, 2, 69-136.

Enders, W. (1995). Applied Econometric Time Series. New York: J. Wiley and Sons.

Eichholtz, P. M. A., Hoesli, M., MacGregor, B. D., \& Nanthakumaran, N. (1995). Real estate diversification by property type and region. Journal of Property Finance, 6, 39-59.

Elliott, G. T., Rothenberg, J., \& Stock, G. H. (1996). Efficient tests for an autoregressive unit root. Econometrica, 64, 813-836.

Engle, R. F., \& Issler, J. V. (1995). Estimating common sectoral cycles. Journal of Monetary Economics, 35, $83-113$.

Fisher, J. D., \& Liang, Y. (2000). Is sector diversification more important than regional diversification? Real Estate Finance, 17, 35-59.

Forbes, K., \& Rigobon, R. (2002). No contagion, only interdependence, measuring stock market comovements. Journal of Finance, 57, 2223-2261.

Francis, J., \& Ibbotson, R. (2009). Contrasting real estate with comparable investments, 1978 to 2008. The Journal of Portfolio Management, 36, 141-155.

Glascock, J. L., \& Kelly, L. J. (2007). The relative effect of property type and country factors in reduction of risk of internationally diversified real estate portfolios. Journal of Real Estate Finanance and Economics, 34, 369-384.

Granger, C. W. J., \& Newbold, P. (1974). Spurious regressions in economics. Journal of Econometrics, 2, 1120.

Granger, C. W. J. (1988). Some recent developments in the concept of causality. Journal of Econometrics, 39, 199-211.

Guo, F., Chen, C. R., \& Huang, Y. S. (2011). Markets contagion during financial crisis, A regime-switching approach. International Review of Economics and Finance, 20, 95-109.

Hamilton, J. D. (1994). Time series analysis. Princeton: Princeton University Press.

Hamao, Y., Masulis, R. W., \& Ng, V. (1990). Correlations in price changes and volatility across international stock markets. Review of Financial Studies, 3, 281-308.

Hamelink, F., Hoesli, M., Lizieri, C., \& MacGregor, B. D. (2000). Homogeneous commercial property markets groupings and portfolio construction in the United Kingdom. Environment and Planning, 32, 323-344.

Haug, A. A. M., MacKinnon, J. G., \& Micehlis, L. (2000). European monetary union: A cointegration analysis. Journal of International Money and Finance, 19, 419-432. 
Hendry, D. F. (1995). Dynamic econometrics. Oxford: Oxford University Press.

Huberman, G., \& Kandel, S. (1987). Mean-variance spanning. Journal of Finance, 42, 873-888.

Johansen, S. (1988). Statistical analysis of cointegration vectors. Journal of Economic Dynamics and Control, 12, 231-254.

Johansen, S., \& Juselius, K. (1990). Maximum likelihood estimation and inference on cointegration with applications to the demand for money. Oxford Bulletin of Economics and Statistics, 52, 169-210.

Kan, R., \& Zhou, G. (2001). Test of mean-variance spanning. Working Paper, University of Toronto.

Kan, R., \& Zhou, G. (2012). Tests of mean-variance spanning. Annals of Economics and Finance, 13, 145193.

Khaled, A., Taamoutib, A., \& Tsafacka, G. (2011). What drives international equity correlations? Volatility or market direction? Journal of International Money and Finance, 30, 1234-1263.

Kasa, K. (1992). Common stochastic trends in international stock markets. Journal of Monetary Economics, 29, 95-124.

Kenourgios, D., Samitas, A., \& Paltalidis, N. (2011). Financial crises and stock market contagion in a multivariate time-varying asymmetric framework. Journal of International Financial Markets, Institutions \& Money, 21, 92-106.

King, M., \& Wadhwani, S. (1990). Transmission of volatility between stock markets. Review of Financial Studies, 3, 5-33.

Lee, S., \& Stevenson, S. (2005). Testing the statistical significance of sector and regional diversification. Journal of Property Investment \& Finance, 23, 394-411.

Lee, J., \& Strazicich, M. C. (2003). Minimum lagrange multiplier unit root test with two structural breaks. The Review of Economics and Statistics, 85, 1082-1089.

Lee, J., \& Strazicich, M. C. (2013). Minimum LM unit root test with one structural break. Economics Bulletin, 33, 2843-2942.

Ling, D. C., \& Naranjo, A. (1999). The integration of commercial real estate markets and stock markets. Real Estate Economics, 27, 483-515.

Ling, D. C., \& Naranjo, A. (1996). Economic risk factors and commercial real estate returns. Journal of Real Estate Finance and Economics, 14, 283-307.

Liow, K. H., \& Yang, H. (2005). Long term co-memories and short-run adjustment: Securitized real estate and stock. Journal of Real Estate Finance and Economics, 31, 283-300.

Long, J. B., \& Plosser, C. I. (1987). Sectoral vs. aggregate shocks in the business cycles. American Economic Review, 77, 333-336.

Louargand, M. A. (1992). A survey of pension fund real estate portfolio risk management practices. Journal of Real Estate Research, 7, 361-373.

Macgregor, B., \& Schwann, G. (2003). Common features in UK commercial real estate returns. Journal of Property Research, 20, 23-48.

McCue, T. E., \& King, J. L. (1994). Real estate returns and the macroeconomy: Some empirical evidence from real estate investment trust. Journal of Real Estate Research, 9, 277-288.

Miles, M. E., \& McCue, T. E. (1982). Historic returns and institutional real estate portfolios. AREUEA Journal, 10, 184-198.

Miles, M. E., \& McCue, T. E. (1984). Commercial real estate returns. Real Estate Economics, 12, 355-377.

Mueller, G. R. (1993). Refining economic diversification strategies for real estate portfolios. Journal of Real Estate Research, 8, 55-68.

Mueller, G. R., \& Ziering, B. A. (1992). Real estate portfolio diversification using economic diversification. Journal of Real Estate Research, 7, 375-386.

Newell, G., \& Keng, T. Y. (2003). The significance of property sector and geographical diversification in Australian institutional property portfolios. Pacific Rim Property Research Journal, 9, 248-264.

Ng, S., \& Perron, P. (2001). Lag length selection and the construction of unit root tests with good size and power. Econometrica, 69, 1519-1554.

Osterwald-Lenum, M. (1992). A note with quartiles as the asymptotic distribution of the maximum likelihood cointegration rank test statistics. Oxford Bulletin of Economics and Statistics, 54, 461-472.

Phillips, P. C. B., \& Perron, P. (1988). Testing for a unit root in time series regression. Biometrika, 75, 335346.

Perron, P. (1997). Further evidence on breaking trend functions in macroeconomic variables. Journal of Econometrics, 80, 355-385.

Phylaktis, K., \& Ravazzolo, F. (2005). Stock market linkages in emerging markets, implications for international portfolio diversification. Journal of International Financial Markets, Institutions \& Money, 15, 91106. 
Quan, D., \& Titman, S. (1999). Do real estate prices and stock prices move together? An international analysis. Real Estate Economics, 27, 183-207.

Rezayat, F., \& Yavas, B. F. (2006). International portfolio diversification: A study of linkages among the U.S., European and Japanese equity markets. Journal of Multinational Financial Management, 16, 440-458.

Roll, R. (1992). A mean variance analysis of tracking error. Journal of Portfolio Management, 18, $13-22$.

Sheng, H., \& Tu, A. (2000). A study of cointegration and variance decomposition among national equity indices before and during the period of the Asian financial crisis. Journal of Multinational Financial Management, 10, 345-365.

Stock, J. H., \& Watson, M. W. (1988). Testing for Common Trends. Journal of the American Statistical Association, 83, 1097-1107.

Switzer, L. N., \& Fan, H. (2007). Spanning tests for replicable small-cap indexes as separate asset classes. Quarterly The Journal of Portfolio Management, 33, 102-110.

Syriopoulos, T. (2006). Risk and return implications from investing in emerging European stock markets. Journal of International Financial Markets, Institutions \& Money, 16, 283-929.

Wit, I. D. (1996). Real estate portfolio management practices of pension funds and insurance companies in The Netherlands, a survey. Journal of Real Estate Research, 11, 131-148.

Wit, I. D. (2010). International diversification strategies for direct real estate. Journal of Real Estate Finanance and Economics, 41, 433-457.

Webb, J. R. (1984). Real estate investment acquisition rules for life insurance companies and pension funds, a survey. AREUEA Journal, 12, 495-520.

Yunus, N. (2012). Modelling relationships among securitized property markets, stock markets and macroeconomic fundamentals, international evidence. Journal of Real Estate Research, 34, 127-156.

Yunus, N. (2013). Dynamic interactions among property types. International evidence based on cointegration test, Journal of Property Investment and Finance, 31, 135-159.

Zivot, E., \& Andrews, D. W. K. (1992). Further evidence on the great crash, the oil-price shock and the unitroot hypothesis. Journal of Business and Economic Statistics, 10, 251-270. 
Reproduced with permission of copyright owner.

Further reproduction prohibited without permission. 